\title{
TRANSPARENCY AND AUTHENTICITY OF SOCIAL MEDIA USAGE: THE CASE OF SLOVAK CITIES
}

https://doi.org/10.47743/jopafl-2021-22-03

\author{
Ondrej MITAL \\ University of Pavol Jozef Šafárik in Košice, Faculty of Public Administration, \\ Department of the Public Policy and the Theory of Public Administration \\ Košice, Slovakia \\ ondrej.mital@upjs.sk
}

\begin{abstract}
Regarding the impacts of social media on the execution of public administration, the states try to find optimal solutions, which might help to increase the qualitative aspects of public governance. The aim of the study is to examine the use of official Facebook pages by Slovak cities, more precisely the basic aspects connected with authenticity and transparency of official Facebook pages. Altogether 124 official Facebook pages of Slovak cities were analysed. The main finding is based on the statement that the public administration must secure the authenticity and transparency of their official Facebook pages, mainly multichannel features and fully filled out information about the official Facebook page. The ambition of the study was also interested in contributing to the standardization of strategies on social media usage in the public administration.
\end{abstract}

Keywords: Social media, Facebook, Municipality, Transparency

\section{Introduction}

The impacts of information technologies on the execution of public administration are mostly discussed as significant challenge of contemporary governance. However, various positive, negative and contradictory impacts of information technologies can be discussed for a long time, but most of them relate to the fact that the role of information technologies is irreplaceable (Cigu et. al, 2020; Ručinská \& Fečko, 2020; Toader et. al, 2018). Simultaneously, the role of engaged public is irreplaceable in current democratic states governed by the rule of law. Regarding the contemporary crisis of democracy, it is necessary to implement solutions focused on the new forms of communication. We might identify the growing importance of innovative forms of communication, which have the potential to share information to citizens more effectively than traditional platforms used so far. Informed citizens can collaborate with public administration to achieve better quality of public services and higher quality of life.

The quality of information shared by public administration seems to be more important than in the past. According to G.A. Porumbescu (2016) organizations of public administration are today disclosing more information than ever before. Regarding the growing use of new and modern tools, public administration has started to use social media as an alternative communication platform. Comparing to traditional platforms, social media bring qualitatively different level of interactivity among users, official profiles on social media are also capable to reach broader public and have the potential and the ability to promote online civic participation (P. Silva et al., 2019; Warren et al., 2014; Bregman, 2012). The use of social media might be characterized as a crosscutting problem of contemporary governance. Public administration organizations are still developing 
universal operating procedures on how to monitor and share information on social media, as well as prepare strategies aimed at their audiences (Charest et. al, 2016; Wukich \& Mergel, 2016). Regarding the growing importance of social media in the sphere of public administration, the purpose of the study is to examine the Facebook usage by local selfgovernment units in Slovakia. In this sense, the aim of the study is to examine selected general aspect of the Facebook usage by the cities, more precisely transparency and authenticity of official Facebook pages. Altogether 124 official Facebook pages of Slovak cities were analysed, while the study reflect the conditions at the end of the year 2020 . Besides, the article tries to provide theoretical and practical insight to the importance of social media usage in public administration.

The study consists of three parts. The theoretical introduction concentrates its attention on the use of social media in the sphere of public administration. The second part examines selected aspects of social media usage connected with transparency and authenticity of official Facebook pages. Regarding the findings the article ends with a discussion about the importance of transparency, authenticity and validity of information shared on official social media profiles.

\section{Literature review: the role of social media in contemporary governance}

Participation and engagement have mostly been discussed in their connections to social media in the last few years. Overall, social media are the phenomenon of last decade. Social media, such as Facebook, Instagram, Twitter or YouTube, are platforms which have potential to connect billions of users and have ability to transform the way people are accessing, reading and spreading the information (Driss et al., 2019). Social media and their impacts on society continue to grow, and there is no evidence that this popularity is slowing or stopping (Siena et al., 2019; Toscano, 2017). This statement is intensified by the argument mentioned by the I. Mergel (2017) that social media are free and do not need to build and maintain the technological background. The power of social media to connect people and information in real time is increasing the capacity of people to exercise power and mobilize into action, because many groups can be reached very easily (Sihi, 2018; LevOn \& Steinfeld, 2015; Bourgon, 2011). Put differently, the use of social media and information included on social media profiles affect almost each sphere of our society, especially patterns of behaviour, hierarchy of values and opinions of individuals.

\section{The use of social media: Towards open transparent public administration}

The impacts of social media on the execution of public administration can be identified in the activities of state across all levels of governance. Governments use social media as a tool, which could make mutual communication with the public more effective and more focused on the needs of the digital public (Lee \& Reed, 2015; Lovari \& Parisi, 2015). In this sense, social media bring sophisticated mechanisms, which can enrich communication and interactions between public administration and citizens. In this sense, social media represent the ideal of open and instant communication in modern public governance. Social media in this sense help to create more open and transparent public administration (Eom et al., 2018; Stamati et al., 2015; Picazo-Vela et al., 2012). The implementation of social media should be based on an openness to share, a clear 
understanding of transparency, as well as a desire to work collaboratively (Miller 2011). In this sense, social media have the potential to share relevant information to the key stakeholders in policymaking. However, social media cannot be defined just as a platform for two-way communication between public administration and citizens. This view is limited and does not describe the real importance of social media for both society and public administration. Citizens' engagement and participation does not rely on traditional mechanisms but is based on authentic and interactive dialogue, which produces positive effects on decision-making, collaboration, citizenship, and governance (Brainard, 2016; Laforest, 2014, Denhardt \& Denhardt, 2015). In this context, social media have the potential to raise public awareness of the execution of public administration functions. This can help citizens and governments, as partners, to be more informed, make socially responsible decisions and to transform governance system at the city, region or state level (Bonsón et al., 2015; Picazo-Vela et al., 2012). This interactive dialog is possible thanks to social media, because according to T. Stamati et al. (2015) social media helps to transform the role of citizen from a passive adopter to a co-creator of public policies. Social media have the potential to create an environment where citizens can express their opinions and feel more involved in the management of organization, measurement of its performance and at the same time feel more responsible for a certain territory (Todisco et. al., 2021; Hartmann, 2019; Dimitrijevska-Markoski, 2018). Summing it up, social media should be described as a tool which helps public administration to serve citizens more effectively, to improve participation of citizens and their engagement, and at the same time helps public administration organizations to reduce organizational costs.

\section{Social media: A universal solution or cross-cutting problem for public administration organizations?}

Social media represent a brand-new communication platform between public administration and the public, which is thanks to interactivity, simplicity and immediacy different from interaction tools used so far. Regarding the courage of public administration organization to use social media the beginning of this journey is relatively simple. However, having a social media icon on official website do not demonstrate the usage (Henrique et al., 2013). According to the T. J. Snead (2013) it is better to have fewer types of media and better interaction with community members than to engage in more types of media with minimal interaction. The social media usage seems to be very simple and nonproblematic. On the other hand, various risks and threats must be managed by the organization and administrators of social media pages. However, is not only an opportunity for public administration to use social media, but it also appears mandatory to avoid someone else playing the role of certain organization of public administration, providing ambiguous information to citizens (Agostino, 2013). As was stated by T. Fyfe and P. Crookall (2010) there is considerable pressure on public administration to implement social media, because there is a legitimate fear that public administration will be left behind; thus social media might improve the decentralization of the decision-making process, empower collaboration, and achieve a better quality of services. Public administration use social media also to improve organizational image, to prepare more inclusive policy processes, as well as to share citizens' opinions and ideas to improve public services delivery, 
governmental effectiveness, and the quality of life (Alcaide-Muñoz \& Rodríguez Bolívar, 2019; Jukić \& Svete, 2018; Špaček, 2018).

The benefits of social media usage must be also discussed in the context of potential risks and threats. In this sense, it is not suitable to omit any relevant individuals or groups in policymaking process based on information shared only on social media pages. Put differently, social media can not be perceived as key communication channel between public administration and citizens. Regarding the need of a systematic approach social media activities should be based on a sophisticated strategy. We might agree with R. Laforest (2013) that social media strategies need to be a part of a larger institutional framework for engagement policy that helps democracy work. Using the words of Hrdinová et al. (2010) the core elements of social media policy include employees' access, account management, acceptable use, employees' conduct, content, security, legal issues, and citizens' conduct. Public administration organizations could very easily create their official social media pages, but at least the following aspects of social media usage should be considered: social media policy with goals, tools and objectives, staff to make sure that content is up to date, the ability to protect and monitor the site to secure the site is not abused or hijacked, as well as solve problems such as security, privacy, records management (Shark, 2015; McNutt, 2008). Some disadvantages of social media usage in the sphere of public administration result from the fundamental basis of social media. Broadly speaking, information communication technologies have brought new specific problems connected with the protection of privacy and personal data. This challenge of new technologies is sensitively discussed especially in the case of e-health, e-taxes, as well as security of cloud solutions.

Besides, the official social media pages can also be hijacked or duplicated, and this is the real problem for the implementation of democratic principles. In this context, naive use of social media might lead to information asymmetry, while the concepts of democracy, civic engagement, and justice, might become placed at risk (Zavattaro \& Sementelli, 2014). Based on abovementioned, social media usage needs to be considered in wider circumstances. Otherwise, the ideal of public administration, collaborating with the digital and informed public through the social media would not be reached.

Using the words of K. Miňová (2020) the main threat is not just the simple abusing and misusing of data, because it is important to deal with secondary impacts of these negative tendencies, which cause change of individuals' behaviour and deciding influenced by disinformation. In this sense, the relevancy and correctness of information published on social media is also questionable, because social media represent the main space for spreading disinformation and hoaxes. This is the main reason for the citizens to verify information and official Facebook profiles of public administration organizations.

Based on abovementioned, the use of social media in the sphere of public administration can be recognized as logical reflection of their current importance and usage by individuals. We must admit that the number of similar studies has increased at municipal level in the last few years, mainly analyses of Facebook usage in European territory (Jukić \& Svete, 2018; Murray Svidroňová et al., 2018; Levkov, 2017; Gesuele 2016; Bonsón et al., 2015; Lev-On \& Steinfeld, 2015; Agostino, 2013). The mentioned papers examined various important aspects of social media usage, such as basic aspects of social media usage, number of posts, purpose of the posts. On the other hand, official social media profiles must reflect some minimal requirements on their validity and authenticity of shared 
information. In this context, the basic aspects of social media usage and profile information must be discussed precisely by the theoreticians, practitioners, and citizens as well.

\section{Methodology}

The focus of this article is put on the basic aspects of social media usage, while most previous studies concentrated their attention on interactions with citizens and their reactions. The aim of the study is to examine the use of official Facebook pages by Slovak cities, more precisely the basic aspects connected with authenticity and transparency of official Facebook pages. Put differently, the authenticity and transparency of the social media activities are determined by the actual and complete profile information, interconnection with other communication platforms, as well as the audience size. In this sense, the paper tries to answer these research questions: How many cities have created official Facebook page and actively share information via official Facebook page? Do examined official Facebook pages include actual and relevant information? Do social media pages include direct connection to other informational platforms? What is the size of the audience in the cases of examined cities? The selected groups of indicators (Table 1) were inspired mainly by the methodologies applied in previous studies on social media usage by local self-government units in different countries, such as Greece, Italy, Israel, Macedonia, or Slovenia (Jukić \& Svete 2018; Lappas et al. 2018; Levkov, 2017; Gesuele, 2016; Lev-On \& Steinfeld 2015, Agostino, 2013). However, these methodologies were slightly adjusted. The indicators related to general aspects were adjusted to our research questions and Facebook updates.

Table 1: Set of Indicators

\begin{tabular}{|c|c|c|}
\hline Group & Indicator & Indicator's value \\
\hline \multirow{10}{*}{ 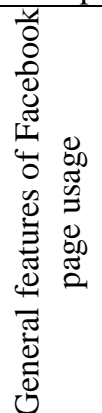 } & Existence of official FB page & Yes/no \\
\hline & Availability of link to the official FB page on the city's web page & Yes/no \\
\hline & Availability of link to the official web page on the official FB & Yes/no \\
\hline & Availability of link to the other social media & Yes/no \\
\hline & Creation of official page & Year \\
\hline & Fully filled out information about the FB page & Complete/incomplete \\
\hline & Number of fans (December 31st, 2019) & Number \\
\hline & Number of inhabitants & Number \\
\hline & Fans to number of inhabitants ratio & Number \\
\hline & Rating and review section & On/off \\
\hline
\end{tabular}

The research sample was selected intentionally. The study analyses the usage of official Facebook pages of 124 cities in Slovakia. Local self-government is a specific public activity different from the state, which is focused on public issues, has a powerful impact on living standards and serves to promote the democratic values of society (Vernarský, 2019; Župová, 2018; Jesenko 2017; Mäeltsemees et al., 2013). Selected cities (local self-government units) are mostly perceived as initiators of innovative solutions in Slovakia. Data were collected in 2020, to provide information detail information about basic aspects of social media usage by selected groups of local self-government units, as of 31st December 2020. Obtained information and data were collected manually by 
analysing social media pages of selected group of local self-government units (external desk research).

\section{Results}

The paper focuses on the transparency and authenticity of social media usage by Slovak cities. Based on the methodology and research questions, the analysis was dedicated to presence of the selected cities on Facebook, interconnection between the official Facebook page and website or other communication platforms, the relevancy of profile information and review section, as well as the size of the audience. The simple presence on social network is not the key to the success. However, the presence of selected cities on the Facebook was the first and important part of our analysis. Altogether 124 cities $(87,74 \%)$ created their official Facebook page. Each of analysed page can be characterized as active and maintained by the city. Important attribute of trustiness of Facebook page is the date when the page was created (Figure 1).

Figure 1: The creation of official Facebook page

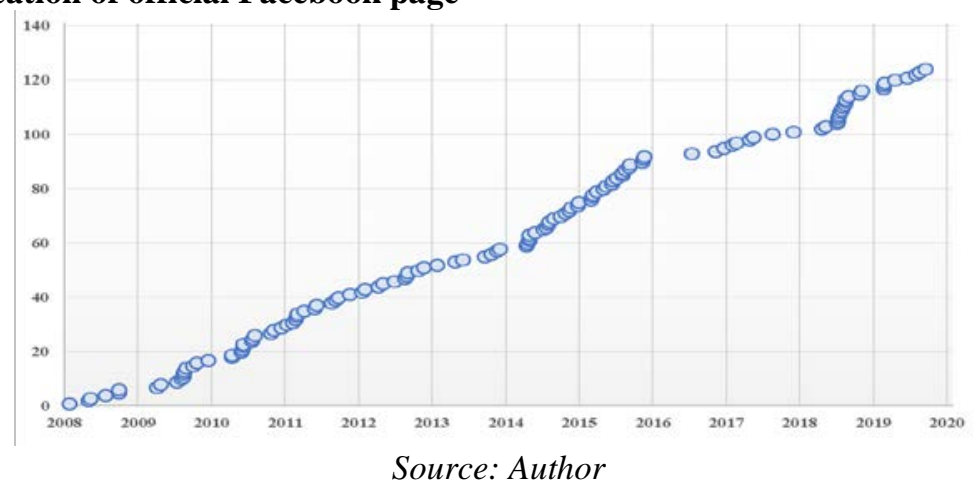

Based on our analysis, the first official Facebook pages of were created page in 2008. Constantly growing importance of social media in public administration defined by the theoreticians, is also confirmed by presented data. According to obtained data, almost one-third (35 pages) of all currently active official Facebook pages of Slovak cities were created between 2008 and 2011. The highest growth was identified between 2014 and 2016. More precisely, 39 official Facebook pages were created in this two-year period. Another intensive growth was identified at the turn of the 2018 and 2019, when 10 official Facebook pages of Slovak cities were created. Regarding the importance of transparency and openness, the size of the audience is also important in public administration. Information about number of fans and fans to number of inhabitants ratio are presented in Table 2, while the attention is put on 10 cities with the highest and the lowest number of fans. 
Table 2. Fans to number of inhabitants ratio (by number of fans criteria)

\begin{tabular}{|c|c|c|c|c|c|c|c|}
\hline $\begin{array}{l}\text { Cities with the highest } \\
\text { number of fans }\end{array}$ & 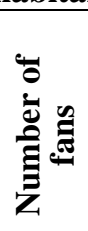 & 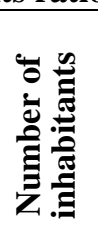 & 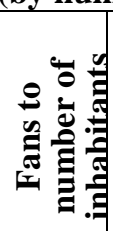 & $\begin{array}{l}\text { Cities with the lowest } \\
\text { number of fans }\end{array}$ & 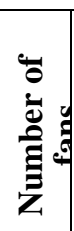 & 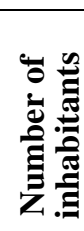 & 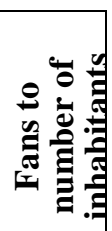 \\
\hline Bratislava & $\begin{array}{c}44,1 \\
00\end{array}$ & $\begin{array}{c}429,5 \\
64\end{array}$ & $\begin{array}{c}10.2 \\
7 \%\end{array}$ & Sliač & $\begin{array}{c}45 \\
0\end{array}$ & $\begin{array}{c}4,98 \\
0\end{array}$ & $\begin{array}{c}9.04 \\
\%\end{array}$ \\
\hline Trnava & $\begin{array}{c}28,1 \\
10\end{array}$ & $\begin{array}{c}65,38 \\
2\end{array}$ & $\begin{array}{c}42.9 \\
9 \% \\
\end{array}$ & Rajecké Teplice & $\begin{array}{c}49 \\
7 \\
\end{array}$ & $\begin{array}{c}3,00 \\
8\end{array}$ & $\begin{array}{c}16.5 \\
2 \%\end{array}$ \\
\hline Nitra & $\begin{array}{c}23,7 \\
00\end{array}$ & $\begin{array}{c}77,04 \\
8\end{array}$ & $\begin{array}{c}30.7 \\
6 \%\end{array}$ & Poltár & $\begin{array}{c}59 \\
9\end{array}$ & $\begin{array}{c}5,69 \\
3\end{array}$ & $\begin{array}{c}10.5 \\
2 \%\end{array}$ \\
\hline Košice & $\begin{array}{c}21,8 \\
72\end{array}$ & $\begin{array}{c}239,0 \\
95\end{array}$ & $\begin{array}{c}9.15 \\
\%\end{array}$ & Spišská Stará Ves & \begin{tabular}{|c|}
65 \\
8
\end{tabular} & $\begin{array}{c}20,3 \\
02\end{array}$ & $\begin{array}{c}3.24 \\
\%\end{array}$ \\
\hline Prešov & $\begin{array}{c}19,8 \\
72\end{array}$ & $\begin{array}{c}89,13 \\
8\end{array}$ & $\begin{array}{c}22.2 \\
9 \%\end{array}$ & Liptovský Hrádok & \begin{tabular}{|c|}
69 \\
6
\end{tabular} & $\begin{array}{c}7,52 \\
8\end{array}$ & $\begin{array}{c}9.25 \\
\%\end{array}$ \\
\hline Poprad & $\begin{array}{c}19,8 \\
48\end{array}$ & $\begin{array}{c}51,48 \\
6\end{array}$ & $\begin{array}{c}38.5 \\
5 \%\end{array}$ & Stará Turá & \begin{tabular}{|c|}
82 \\
1
\end{tabular} & $\begin{array}{c}8,93 \\
2\end{array}$ & $\begin{array}{c}9.19 \\
\%\end{array}$ \\
\hline Banská Bystrica & $\begin{array}{c}17,7 \\
72\end{array}$ & $\begin{array}{c}78,48 \\
4\end{array}$ & $\begin{array}{c}22.6 \\
4 \%\end{array}$ & Šurany & \begin{tabular}{|c|}
89 \\
0
\end{tabular} & $\begin{array}{c}9,78 \\
8\end{array}$ & $\begin{array}{c}9.09 \\
\%\end{array}$ \\
\hline Žilina & $\begin{array}{c}17,2 \\
00\end{array}$ & $\begin{array}{c}80,97 \\
8\end{array}$ & $\begin{array}{c}21.2 \\
4 \%\end{array}$ & Svätý Jur & \begin{tabular}{|c|}
93 \\
8
\end{tabular} & $\begin{array}{c}5,65 \\
5\end{array}$ & $\begin{array}{c}16.5 \\
9 \%\end{array}$ \\
\hline Spišská Nová Ves & $\begin{array}{c}14,2 \\
80\end{array}$ & $\begin{array}{c}37,32 \\
6 \\
\end{array}$ & $\begin{array}{c}38.2 \\
6 \% \\
\end{array}$ & Gbely & \begin{tabular}{|c|}
95 \\
3 \\
\end{tabular} & $\begin{array}{c}5,15 \\
5\end{array}$ & $\begin{array}{c}18.4 \\
9 \% \\
\end{array}$ \\
\hline Trenčín & $\begin{array}{c}14,2 \\
30\end{array}$ & $\begin{array}{c}55,53 \\
7\end{array}$ & $\begin{array}{c}25.6 \\
2 \%\end{array}$ & Nemšová & \begin{tabular}{|c|}
97 \\
8 \\
\end{tabular} & $\begin{array}{c}6,36 \\
8\end{array}$ & $\begin{array}{c}15.3 \\
6 \% \\
\end{array}$ \\
\hline
\end{tabular}

Source: Author

Altogether 653375 fans were identified in the case of 124 official Facebook pages of the Slovak cities. The average number of fans in the selected group of cities is 5,312. The highest number of fans was identified in the cases of the largest cities. According to our analysis, the highest number of fans have official Facebook pages of eight regional and most crowded cities. However, Poprad and Spišská Nová Ves do not represent regional cities. But these two cities achieve high number of fans as well as high fans to number of inhabitants ratio. On the opposite site of the scale, the cities do not reach 1,000 fans mark on their official Facebook pages. However, many of these cities have reached higher fans to number of inhabitants ratio than two biggest cities in Slovakia, Bratislava and Košice. Subsequently, it was very important to examine number of fans of official Facebook pages with an emphasize on number of inhabitants (Table 3).

Table 3. Fans to number of inhabitants ratio (by fans to number of inhabitants ratio criteria)

\begin{tabular}{|c|c|c|c|c|c|c|c|}
\hline $\begin{array}{l}\text { Cities with the highest fans to } \\
\text { number of inhabitants ratio }\end{array}$ & 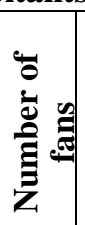 & 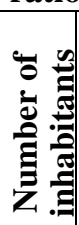 & 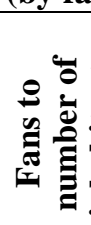 & $\begin{array}{l}\text { Cities with the lowest fans to } \\
\text { number of inhabitants ratio }\end{array}$ & 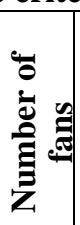 & 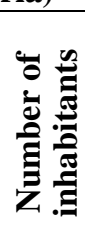 & 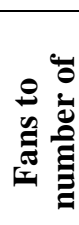 \\
\hline Trenčianske Teplice & $\begin{array}{l}7,5 \\
06 \\
\end{array}$ & $\begin{array}{l}4,1 \\
77 \\
\end{array}$ & $\begin{array}{l}179 . \\
70 \% \\
\end{array}$ & Spišská Stará Ves & $\begin{array}{c}65 \\
8\end{array}$ & $\begin{array}{l}20 \\
302\end{array}$ & $\begin{array}{l}3.2 \\
4 \%\end{array}$ \\
\hline Námestovo & $\begin{array}{c}11 \\
60 \\
7\end{array}$ & $\begin{array}{l}7,8 \\
68\end{array}$ & $\begin{array}{l}147 . \\
52 \%\end{array}$ & Nové Mesto nad Váhom & $\begin{array}{l}1,6 \\
52\end{array}$ & $\begin{array}{l}20 \\
066\end{array}$ & $\begin{array}{l}8.2 \\
3 \%\end{array}$ \\
\hline
\end{tabular}




\begin{tabular}{|c|c|c|c|c|c|c|c|}
\hline Banská Štiavnica & $\begin{array}{c}11, \\
30 \\
0\end{array}$ & $\begin{array}{c}10 \\
09 \\
7\end{array}$ & $\begin{array}{l}111 . \\
91 \%\end{array}$ & Sliač & $\begin{array}{c}45 \\
0\end{array}$ & $\begin{array}{c}4,9 \\
80\end{array}$ & $\begin{array}{l}9.0 \\
4 \%\end{array}$ \\
\hline Modrý Kameň & $\begin{array}{r}1,5 \\
64 \\
\end{array}$ & $\begin{array}{l}1,5 \\
97 \\
\end{array}$ & $\begin{array}{c}97.9 \\
3 \% \\
\end{array}$ & Šurany & $\begin{array}{c}89 \\
0 \\
\end{array}$ & $\begin{array}{c}9,7 \\
88 \\
\end{array}$ & $\begin{array}{l}9.0 \\
9 \% \\
\end{array}$ \\
\hline Modra & $\begin{array}{c}7,1 \\
42\end{array}$ & $\begin{array}{l}8,9 \\
76\end{array}$ & $\begin{array}{c}79.5 \\
7 \%\end{array}$ & Košice & $\begin{array}{c}21, \\
87 \\
2\end{array}$ & $\begin{array}{c}239 \\
, 09 \\
5\end{array}$ & $\begin{array}{l}9.1 \\
5 \%\end{array}$ \\
\hline Gabčíkovo & $\begin{array}{c}4 \\
20 \\
0\end{array}$ & $\begin{array}{l}5,3 \\
91\end{array}$ & $\begin{array}{c}777.9 \\
1 \%\end{array}$ & Stará Turá & $\begin{array}{c}82 \\
1\end{array}$ & $\begin{array}{l}8,9 \\
32\end{array}$ & $\begin{array}{l}9.1 \\
9 \%\end{array}$ \\
\hline Hanušovce nad Topl'ou & $\begin{array}{c}2 \\
82 \\
7\end{array}$ & $\begin{array}{l}3,7 \\
68\end{array}$ & $\begin{array}{c}75.0 \\
3 \%\end{array}$ & Liptovský Hrádok & $\begin{array}{c}69 \\
6\end{array}$ & $\begin{array}{c}7,5 \\
28\end{array}$ & $\begin{array}{l}9.2 \\
5 \%\end{array}$ \\
\hline Dudince & $\begin{array}{c}1 \\
01 \\
6\end{array}$ & $\begin{array}{l}1,4 \\
22\end{array}$ & $\begin{array}{c}71.4 \\
5 \%\end{array}$ & Moldava nad Bodvou & $\begin{array}{l}1,0 \\
61\end{array}$ & $\begin{array}{l}11, \\
342\end{array}$ & $\begin{array}{l}9.3 \\
5 \%\end{array}$ \\
\hline Kremnica & $\begin{array}{c}3 \\
75 \\
8\end{array}$ & $\begin{array}{l}5,3 \\
85\end{array}$ & $\begin{array}{c}69.7 \\
9 \%\end{array}$ & Bratislava & $\begin{array}{c}4, \\
10 \\
0\end{array}$ & $\begin{array}{c}429 \\
, 56 \\
4\end{array}$ & $\begin{array}{l}10 . \\
27 \\
\%\end{array}$ \\
\hline Turany & $\begin{array}{c}2 \\
73 \\
0\end{array}$ & $\begin{array}{l}4,2 \\
75\end{array}$ & $\begin{array}{c}63.8 \\
6 \%\end{array}$ & Poltár & $\begin{array}{c}59 \\
9\end{array}$ & $\begin{array}{c}5,6 \\
93\end{array}$ & $\begin{array}{l}10 . \\
52 \\
\%\end{array}$ \\
\hline
\end{tabular}

Source: Author

The average number of fans to number of inhabitants ratio in the Slovak cities is $32.20 \%$. The highest values of fans to number of inhabitants ratio were identified in cities with 10,000 or less inhabitants. On the other hand, one of the lowest fans to number of inhabitants ratio were identified in the city of Košice and Bratislava, two most populous cities. In this sense, the high number of inhabitants does not automatically provide high number of fans to number of inhabitants ratio. The profile information represents important feature of official Facebook pages of selected local self-government units. Altogether 60 cities (48,39\%) have fulfilled profile information about their official Facebook page in accordance with actual options offered by the Facebook, while the rest of the cities have fulfilled just basic profile information, which were probably available in the moment of page creation. Another general aspect is associated with multichannel features. Put differently, whether cities add a connection to their website, a direct connection to Facebook page on website or a link to other social media accounts. According to our analysis, $100 \%$ of analysed Facebook pages contain a direct link to the official website of given city. On the other hand, a direct link to the Facebook page could not be found on each website of selected group of cities. Various types of connection can only be found only on $71,77 \%$ out of all web pages of Slovakian cities. It is also very important to verify account on other social networking site. In this context, one of the profile functionalities allows administrators to add connection to other social media accounts. However, only 20 official Facebook pages (16,13\%) include direct connection to another social media account, mainly Instagram and YouTube. Facebook allows cities and administrators to add section called as Reviews. This functionality allows cities to make opinions of the citizens available to wider public. The result is also connected with the ranking of certain official Facebook page. However, only 45 cities (36,29\%) have switched this functionality on. The most dominant part of these cities, exactly $40(88,89 \%)$ pages, have reached fivestar rating. 


\section{Discussion}

Regarding the new dimensions of providing information by public administration the social media usage has increased in last decade. This tendency has been proved both by the theory and realized research. The official Facebook pages of the selected cities are a relatively stable part of their image and can be perceived as an accepted communication channel. The analysis of transparency and authenticity features revealed fundamental information about social media usage by selected Slovak cities. Information sharing through the official Facebook pages is low-cost solution for the cities. There are no quantitative limitations associated with sharing information, videos or pictures. If we consider financial and personal costs connected with the maintenance of official website, then the use of social media seems to be very effective. Another benefit of the Facebook usage should be identified in the context of social media coverage because the ability of social media to spread information seems to be unlimited. In our opinion, that is the main reason why almost $90 \%$ of Slovak cities have created their official Facebook page. According to previous research, a relatively high adoption rate of social media by various types of local self-government units was identified in Greece 53\%, Israel 58.1\%, Lithuania 77\%, Romania 83\% and Italy 92\% (Lappas et al. 2018; Sinkienė and Bryer 2016; Urs 2016; Lev-On and Steinfeld 2015; Agostino, 2013). According to previous studies, average number of fans reach 15,260 fans in Romanian local self-government units, 1,877 in the case of Czech self-governing regions and 7,576 in Israel municipalities (Špaček 2018; Urs 2016; Lev-On and Steinfeld 2015). The average number of fans reached in the case of Slovak cities is 5,312 .

However, our research has ambition to bring slightly different view than previous studies focused on basic aspects of the Facebook usage by local-self-government units. According to obtained data, the discrepancy was identified in the context of number of fans, number of citizens and fans to number of inhabitants ratio. This relationship should be key ambition of cities and their activities on social media. In our opinion, it is very important to achieve the highest value of fans to number of inhabitants ratio as it is possible. Based on our research, high number of inhabitants does not automatically provide the highest numbers of fans to number of inhabitants ratio, however the number of inhabitants has been identified as important factor of total number of fans.

Authenticity of official Facebook page is also important part of success, which should be guaranteed by the Facebook, but trust rate of Facebook page must be primarily created by the local self-government units themselves. The verifiability of information is very important in contemporary information society. In this sense, the citizens want to check the profile of their city to make sure that information is coming from the city they live in. Facebook helps users to recognize authentic pages from pages, which try to harm or duplicate the activities of public administration organizations.

Simultaneously, the cities can also fulfil profile optional information of their official Facebook page. The dominant part of analysed pages is older than 5 years. Many actual functionalities were not available in the time when these pages were created. In this sense, the ideal official Facebook page of city should include all possible profile information supported by the Facebook. Put differently, cities should check the possibilities of new profile section options on regular basis. In this sense, we might discuss the complexness of information about the official Facebook page in accordance with actual possibilities offered 
by the Facebook. Our attention was not put only on fundamental and traditional aspects of profile information, such as description, email or web page. The analysis was focused on the newest functionalities, such as opening hours, location, QR code, multichannel features, or categorization of the page. According to obtained data, the half of analysed official Facebook pages $(51,61 \%)$ have not informed citizens about the authenticity of page as much as they could.

Multichannel features of social media seem to be another important factor, which might enhance the transparency of official Facebook pages and subsequently the trust of the citizens in public administration organizations. Interconnection of two dominant platforms for providing information is very beneficial. According to our analysis, $100 \%$ of the selected Facebook pages include a direct link to the official website of city, while only $71,77 \%$ out of all websites include connection to official Facebook page. Regarding the growing importance of social media, the cities have started to use other social media networking sites. The credibility of these sites is sometimes questionable, but official Facebook pages of cities offer very easy solution. In our opinion, it is important to add direct connection to other social media accounts, which were adopted by the certain city. Based on obtained data, only 20 official Facebook of Slovak cities (16,13\%) include direct connection to other social media, mainly Instagram and YouTube. Regarding the growing importance of other social media networking sites, it will be very important for cities to make it easier for citizens to identify official social media accounts of cities on emerging social media networking sites.

The citizens and the wider public, as the users of information shared on official Facebook pages, should be able to identify that shared information is objective, relevant and trustworthy. This can very easily be achieved thanks to the verifiability of the plurality of communication channels between public administration and citizens. In this sense, it is more than necessary to use multichannel features of social media in its connection to official websites of cities, and of course it is important to link the key social media accounts used by the cities to inform the citizens. Ideally, mentioned use of social media multichannel features could limit the spread of misinformation and might help to eliminate hoaxes and untruth. Reviews and rating are also the important feature which helps citizens to verify the authenticity of official Facebook page. This feature was originally created for the business accounts but is also used by public administration organizations. Review feature is another peace of puzzle, which helps citizens to recognize authentic official Facebook pages of cities. Besides, official pages of cities look more transparent with reviews option switched on. However, only 36,26\% of Slovak cities have made decision to give citizens the possibility to rate social media activities of their city.

The benefits of the performed analysis and the defined recommendations should be considered in connection to their limits. The research sample was selected intentionally, and the paper examines only the selected part of public administration (cities). According to this fact, the widening number and type of organizations could be very useful both for theory and practice. It must be said that the paper tries to be an initial insight into the relatively new aspect of public administration activities on social media. In this sense, the analysis of basic attributes of other social networking sites can bring more comprehensive results and recommendations. The paper could foster future research. In this sense, the paper tried to support an interest in deeper research focused on the use of social media in public administration. The benefit of the paper might be a comprehensive view on the 
general aspects of social media usage, thanks to which cities and administrators could prepare and implement better social media policies. Moreover, the paper concentrates its attention to Slovakian cities, but findings could be inspirational for public administration organizations around the world. Besides, the frequency of posts, number of reactions also represent inspirational aim of the research, mainly in the comparison between different countries, different subsystems of public administration or size categories of organizations.

\section{Conclusion}

The use of social media in the sphere of public administration can be recognized as logical reflection of their current importance and popularity among individuals in contemporary society. Regarding the permanent effort of states to bring new communication platforms and despite the negative aspect of their usage, the social media represent platform for better involvement of citizens in governance and policymaking. Utilization of social media usage can be viewed especially in their potential to share information immediately and their ability to create a space for two-way communication between public administration and citizens. The users of social media, as the users of information shared on official Facebook pages, should be able to identify that published information is objective, relevant and trustworthy. In this sense, there are important issues which need to be considered by the management of public organizations, such as multichannel features and fully filled out information about the official Facebook page. It is important to use multichannel features of social media and link the key social media accounts used by the cities. The local self-government units must secure the authenticity and transparency of their official social media profiles to ensure the open dialogue between the state and citizens. Public administration just begins to create standards and social media policies. In this sense, the widening of informational basis is very important for better sophistication of social media usage. The manuscript tried to widen the informational basis of social media usage, which is also very important for better sophistication of social media usage by the managers of public administration organizations and administrators of official social media pages.

Summing it up, social media do not represent the final solution for more effective participation and engagement of citizens in public governance and policymaking, but the use of official social media pages represent relatively new and simple mechanism, which can help public administration to provide valid and relevant information to citizens.

\section{References}

1. Agostino, D., (2013). Using social media to engage citizens: A study of Italian municipalities. Public Relations Review, 39(3), pp. 232-234. DOI: https://doi.org/10.1016/j.pubrev.2013.02.009

2. Alcaide-Muňoz, L. \& Rodríguez Bolívar, M.P., (2019). Using Tools for Citizen Engagement on Large and Medium-Sized European Smart Cities.” In: Alcaide-Muňoz, L. \& Rodríguez Bolívar, M.P. (eds). E-Participation in Smart Cities: Technologies and Models of Governance for Citizen Engagement. Cham: Springer, pp. 23-25.

3. Bonsón, E. et. al., (2015). Citizens' engagement on local governments' Facebook sites. An empirical analysis: The impact of different media and content types in Western Europe. Government Information Quarterly, 32(1), pp. 52-62. https://doi.org/10.1016/j.giq.2014.11.001 
4. Bourgon, J., (2011). A New Synthesis of Public Administration: Serving in the 21st Century. Kingston: Queen's Policy Studies.

5. Brainard, L. A., (2016). Fostering Engagement Through Social Media? The Case of the Washington DC, Metropolitan Police Department. In: Zavattaro, M. S. \& Thomas A. B. (eds). Social Media for Government: Theory and Practice. New York: Routhedge, pp. 117-134.

6. Bregman, S., (2012). Uses of Social Media in Public Transportation: A Synthesis of Transit Practice. Washinghton: Transportation Research Board.

7. Charest, F. et al., (2016). Public relations and social media: Deliberate or creative strategic planning. Public Relations Review, 42(4), pp. 530-538. DOI: https://doi.org/10.1016/j.pubrev.2016.03.008

8. Cigu, E. et al., (2020). The Nexus between Financial Regulation and Green Sustainable Economy. Sustainability, 12(21), 8778. DOI: https://doi.org/10.3390/su12218778

9. Denhardt, J. V. \& Denhardt, R. B., (2015). The New Public Service: Serving, Not Steering. New York: Routledge.

10. Dimitrijevska-Markoski, T., (2018). Exploring Municipal Utilization of Social Media in Performance Measurement and Management. Public Administration Issues, 2018, n. 6 Special Issue II, pp. 98-106.

11. Driss, O. B. et al., (2019). From citizens to government policy-makers: Social media data analysis. Government Information Quarterly, 36(3), 560-570. https://doi.org/10.1016/j.giq.2019.05.002

12. Eom, J. S. et al., (2018). Can social media increase government responsiveness? A case study of Seoul, Korea. Government Information Quarterly, 35(1), pp. 109-122. DOI: https://doi.org/10.1016/j.giq.2017.10.002

13. Fyfe, T. \& Crookall, P., (2010). Social Media and Public Sector Policy Dilemmas. Toronto: Institute of Public Administration, $52 \mathrm{p}$.

14. Gesuele, B., (2016). Municipalities and Facebook Use: Which Key Drivers? Empirical Evidence from Italian Municipalities. International Journal of Public Administration 39(10), pp. 771-777. https://doi.org/10.1080/01900692.2015.1034323.

15. Hartmann, S., (2019). Citizen Relationship Management for Civic Participation: How Smart Cities use to Involve Citizens. In Alcaide-Muňoz, L. \& Rodríguez Bolívar, M.P. (eds). E-Participation in Smart Cities: Technologies and Models of Governance for Citizen Engagement. Cham: Springer, pp. 59-77.

16. Henrique, G. et al., (2013). Social media use in local government: Linkage of technology, task, and organizational context. Government Information Quarterly, 30(4), pp. 397-405. DOI: https://doi.org/10.1016/j.giq.2013.05.019

17. Hrdinová, J, Helbig, N. and Stollar Peters, K., (2010). Designing Social Media Policy for Government: Eight Essential Elements. Albany: Center for Technology in Government.

18. Jesenko, M., (2017). Právo obce na samosprávu a normotvorba obcí. Košice: PJSU in Košice.

19. Jukić, T. \& Svete, B., (2018). The Use of Facebook in the Slovenian Local Self-Government: Empirical Evidence. Central European Public Administration Review, 16(2), pp. 7-22. DOI: https://doi.org/10.17573/cepar.2018.2.01

20. Laforest, R., (2013). Deep and Wide: Citizen Engagement in the Era of Social Media. In: Conteh, CH. \& Roberge, I. (eds). Canadian Public Administration in the 21st Century. Boca Ranton: CRC Press, p. 61-78.

21. Lappas, G. et al., (2018). Facebook Content Strategies and Citizens' Online Engagement: The Case of Greek Local Governments. The Review of Socionetwork Strategies, 12, pp. 1-20. DOI: https://doi.org/10.1007/s12626-018-0017-6.

22. Lee, J. \& Reed, B. J., (2015). From Paper to Cloud. In: Guy, M. E. \& Rubin, M. M. (eds). Public Administration Evolving: From Foundations to the Future. New York: Routledge, pp. 158-191.

23. Levkov, N., (2017). How Macedonian Municipalities are Using Social Media for Public Communication. In: Annual of the Faculty of Economics - Skopje, pp. 199-210. DOI: https://doi.org/352:004.773.6/.7(497.7)

24. Lev-on, A. \& Steinfeld, N., (2015). Social Media and the City: Analyzing Conversations in Municipal Facebook Pages. In: Sobaci, M. Z. (eds). Social Media and Local Governments. Public Administration and Information Technology. Cham: Springer, pp. 234-261.

25. Lovari, A. \& Parisi, L., (2015). Listening to Digital Publics: Investigating Citizens' Voices and Engagement within Italian Municipalities’ Facebook Pages. Public Relations Review, 41(2), pp. 205-213. https://doi.org/10.1016/j.pubrev.2014.11.013. 
26. Mäeltsemees, S. et al., (2013). Inter-Municipal Cooperation: Possibility for Advancing Local Democracy and Subsidiarity in Estonia. Halduskultuur - Administrative Culture, 14(1), pp. 73-97.

27. McNutt, J., (2008). Advocacy Organizations and the Organizational Digital Divide. Currents: Scholarship in the Human Services, 7(2), pp, 1-16.

28. Mergel, I., (2017). Building Holistic Evidence for Social Media Impact. Public Administration Review, 77(4), pp. 489-495. https://doi.org/10.1111/puar.12780

29. Miller, A., (2011). Information Science Reference Cultural barriers to organizational social media adoption. In: Girard, J. P. \& Joann L. G. (eds). Social Knowledge: Using Social Media to Know what You Know. Hershey: IGI Global, pp. 96-114.

30. Miňová, K., (2020). Moral Aspects of the Security of Individuals in the Hyper-connected Society. In: Ušiak, J. \& Kollár, D. (eds.). Security Forum 2020 - 13th Annual International Scientific Conference February 12th- 13th, 2020 at Matej Bel University in Banská Bystrica, Slovakia, Conference Proceedings (pp. 179-191) Banská Bystrica: Interpolis.

31. Murray Svidroňová, M. et al., (2018). Can Social Media be a Tool for Participatory Governance in Slovak Municipalities? NISPAcee Journal of Public Administration and Policy, 11(2), pp. 81-101. DOI: https://doi.org/10.2478/nispa-2018-0014.

32. Picazo-Vela, S. et al., (2016). Opening the black box: Developing strategies to use social media in government. Government Information Quarterly, 33(4), pp. 693-704. https://doi.org/10.1016/j.giq.2016.08.004

33. Porumbescu, G. A., (2016). Linking public sector social media and e-government website use to trust in government. Government Information Quarterly, 33(2), pp. 291-304. https://doi.org/10.1016/j.giq.2016.04.006

34. Ručinská, S. \& Fečko, M. (2020). eServices as a Challenge for Small Municipalities: Slovak Republic Experiences. In: Hemker, T. et al. (ed). Central and Eastern European eDem and eGov Days 2020: Conference Proceedings. Wien: Facultas Verlag, 383-392. DOI:10.24989/ocg.338.30.

35. Shark, A. R., (2015). Technology and Public Management. Routledge: New York, 426 p.

36. Siena, O. et al., (2019). Facebook's use by Local Governments to Promote Accountability with Social Participation. Revista de Direito da Cidade, 11(3), p. 584-616.

37. Sihi, D., (2018). Friending and Funding Through Facebook: Social Media Use of Regional Nonprofit Organizations. In: Manoharan, A. P. \& McQuiston, J. (eds). Innovative Perspectives on Public Administration in the Digital Age. Hershey: IGI Global, p. 256-283. DOI: https://doi.org/10.4018/978-15225-5966-5.ch014

38. Silva, P. et al., (2019). The good, the bad and the ugly: Three faces of social media usage by local governments. Government Information Quarterly, 36(3), $\quad$ pp. 469-479. https://doi.org/10.1016/j.giq.2019.05.006

39. Sinkiene, J. \& Bryer, T. A., (2016). Social Media Adoption and Performance: A First Look at Lithuanian Municipalities. In: 24th NISPAcee Annual Conference. Zagreb, Croatia, 19-21 May 2016.

40. Snead, T. J., (2013). Social media use in the U.S. Executive branch. Government Information Quarterly, 30(1), pp. 56-63. https://doi.org/10.1016/j.giq.2012.09.001

41. Sobaci, M. Z., (2016). Social Media and Local Governments: An Overview. In: Sobaci, M. Z. (eds). Social Media and Local Governments. Public Administration and Information Technology. Springer, Cham, pp. 3-21.

42. Šspaček, D., (2018). Social Media Use in Public Administration: The Case of Facebook Use by Czech Regions. NISPAcee Journal of Public Administration and Policy. 11(2), p 199-218. DOI: https://doi.org/10.2478/nispa-2018-0019

43. Stamati, T. et al., (2015). Social media for openness and accountability in the public sector: Cases in the Greek context. Government Information Quarterly, 32(1), pp. 12-29. https://doi.org/10.1016/j.giq.2014.11.004

44. Toader, E. et al., (2018). Impact of Information and Communication Technology Infrastructure on Economic Growth: An Empirical Assessment for the EU Countries. Sustainability, 10(10), 3750; DOI: https://doi.org/10.3390/su10103750

45. Todisco, L. et. al., (2021). Exploring social media usage in the public sector: Public employees' perceptions of ICT's usefulness in delivering value added. Socio-Economic Planning Sciences, 73(February 2021), 100858. DOI: https://doi.org/10.1016/j.seps.2020.100858 
46. Toscano, J. P., (2017). Social Media and Public Participation: Opportunities, Barriers and a New Framework. In: Adria, M. \& Mao. Y. (eds.): Handbook of Research on Citizen Engagement and Public Participation in the Era of New Media. Hershey: IGI Global, pp. 73-89.

47. Urs, N., (2016). Online Services and Social Media Use in Romanian Cities: Can We See a Pattern? In: 24th NISPAcee Annual Conference. Zagreb, Croatia, 19-21 May $2016 . \quad$ DOI: http://dx.doi.org/10.2139/ssrn.3044274.

48. Vernarský, M. (2019). Current State's Attitude Towards Municipal Self-Government in Slovakia. Slovak Journal of Political Sciences, 19(2), pp. 49-74. DOI: https://doi.org/10.34135/sjps.190203

49. Warren, M. A. et al., (2014). Social media effects on fostering online civic engagement and building citizen trust and trust in institutions. Government Information Quarterly, 31(2), pp. 291-301. https://doi.org/10.1016/j.giq.2013.11.007

50. Wukich, C. \& Mergel, I., (2016). Reusing social media information in government. Government Information Quarterly, 33(2), pp. 305-312. DOI: https://doi.org/10.1016/j.giq.2016.01.011

51. Zavattaro, S. M. \& Sementelli, J., (2014). A critical examination of social media adoption in government: Introducing omnipresence. Government Information Quarterly, 31(2), pp. 257-264. DOI: https://doi.org/10.1016/j.giq.2013.10.007

52. Župová, E., (2018). Mayor in the Local Self-government in Slovakia and Electoral Trends and Characteristics. MEST Journal, 6(2), pp. 167-176. DOI: https://doi.org/10.12709/mest.06.06.02.20 Creative Commons Attribution - Non Commercial - No Derivatives 4.0 International License. 